\title{
PEMIKIRAN IBNU TAIMIYAH DALAM HARGA, PASAR DAN HAK MILIK
}

\author{
${ }^{1}$ Amir Salim, ${ }^{2}$ Muharir, ${ }^{3}$ Alda Hermalia \\ ${ }^{1}$ Sekolah Tinggi Ekonomi Dan Bisnis Syariah (STEBIS) Indo Global Mandiri \\ Email: amirsalim@stebisigm.ac.id \\ ${ }^{2}$ Sekolah Tinggi Ekonomi Dan Bisnis Syariah (STEBIS) Indo Global Mandiri \\ Email: muharir@stebisigm.ac.id \\ ${ }^{3}$ Mahasiswa Sekolah Tinggi Ekonomi Dan Bisnis Syariah (STEBIS) Indo Global Mandiri \\ Email: aldahermalia1711@gmail.com
}

\begin{abstract}
The main points of thought of one of the scholars of Shaykhul Islam Ibn Taymiyyah related to economic issues, Ibn Taymiyyah has a very deep knowledge of future Islamic teachings, a clear economic view of what is now expected and how something can be done. To realize this, freedom in business and property rights is needed, the methodology in this study uses qualitative methods of data collection techniques through books and journals related to the figure of Ibn Taymiyyah in prices, markets and property rights, the results of this study indicate that Ibn Taymiyyah's thoughts were the result of critical dialogue with the social, economic and political phenomena of his time. He has provided inspiration on how a country plays a role in development, particularly economic development
\end{abstract}

Keywords: Ibn Taymiyyah, Prices, Markets, Property Rights

\begin{abstract}
Abstrak
Pokok - pokok pemikiran dari salah satu ulama Syaikhul Islam Ibnu Taimiyah yang berkaitan dengan masalah ekonomi, Ibnu Taimiyah memiliki ilmu pengetahuan yang sangat dalam tentang ajaran islam masa depan, pandangan ekonomi yang jernih tentang apa yang kini diharapkan dan bagaimana sesuatu itu bisa dilakukan. Untuk mewujudkan hal tersebut diperlukan kebebasan dalam berusaha dan hak milik, metodologi pada penelitian ini menggunakan metode kualitatif teknik pengumpulan data melalui buku-buku dan jurnal-jurnal yang berkaitan dengan tokoh ibnu taimiyah dalam harga, pasar dan hak milik, hasil dalam penelitian ini menunjukkan bahwa pemikiran ibnu taimiyah merupakan hasil dialog kritis dengan fenomena sosial, ekonomi dan politik pada zamannya. Ia telah memberikan inspirasi tentang bagaimana sebuah negara berperan dalam pembangunan, khususnya pembangunan ekonomi
\end{abstract}

Kata Kunci: Ibn Taimiyyah, Harga, Pasar, Hak Milik 
156 | Amir Salim, Muharir, Alda Hermalia, Pemikiran Ibnu Taimiyah dalam Harga..................

\section{DASAR PEMIKIRAN}

Kehidupan manusia tidak bisa masuk dalam masalah ekonomi yang melibatkan hubungan antar manusia dengan manusia lainnya, hubungan itu harus didasarkan pada norma - norma agama islam yang membina segala aspek kehidupan termasuk yang berkaitan dengan masalah mu'amalah. Dalam konteks, usaha mengembangkan sistem ekonomi Islam, kita mencoba melihat sebuah konsep pemikiran yang sangat brilian pada waktu itu, sebagai inspirasi dan petunjuk. Untuk itu penulis menyampaikan pernyataan pokok - pokok pikiran dari salah satu ulama yaitu: Syaikhul Islam Ibnu Taimiyah yang berkaitan dengan masalah ekonomi, meskipun jarak antara kita dan lahirnya beliau sangat jauh. Ia hidup pada akhir abad ke 7 dan awal abad ke 8 Hijriah, dia memiliki ilmu pengetahuan yang sangat dalam tentang ajaran islam. Islam masa depan pandangan ekonomi yang jernih tentang apa kini diharapkan dan bagaimana sesuatu itu bisa dilakukan. Untuk mewujudkan hal tersebut diperlukan kebebasan dalam berusaha dan hak milik, yang membangun oleh hukum moral dan diawasi oleh negara yang adil dan mampu menegakkan hukum syari'at. Seluruh kegiatan ekonomi dibolehkan, kecuali yang dilarang oleh syari'at. Sistem ekonomi kapitalis yang sangat kejam muncul dengan sistem bunganya yang sangat tinggi diduga sebagai penyebab terjadinya krisis. Membahas sedikit akan sistem kapitalis ini, Kapitalisme merupakan sebuah sistem organisasi ekonomi yang dicirikan oleh hak milik privat atas alat-alat produksi dan distribusi yang pemanfaatannya untuk mencapai laba dalam kondisi yang sangat kompetitif.

\section{METODE PENELITIAN}

Penelitian ini menggunakan model penelitian kualitatif. Penelitian kualitatif bertujuan memperoleh gambaran seutuhnya mengenai suatu hal menurut pandangan manusia yang diteliti. Penelitian kualitatif adalah prosedur penelitian yang menghasilkan data deskriptifberupa kata-kata tertulis atau lisan dari orang-orang dan perilaku yang diamati (Moleong: 2006). Penelitian kualitatif berhubungan dengan ide, persepsi, pendapat, atau kepercayaan orang yang diteliti; kesemuanya tidak dapat diukur dengan angka (Sulistyo 2006) Metode penelitian dan teknik penelitian merupakan komponen yang paling penting dalam penelitian. Metode merupakan keseluruhan 
langkah ilmiah yang digunakan untuk menemukan solusi atas suatu masalah (Silalahi 2009). Metode penelitian itu sendiri dapat didefinisikan sebagai suatu setiap prosedur yang digunakan untuk mencapai tujuan akhir (Silalahi 2009)

\section{BIOGRAFI IBNU TAIMIYYAH}

\section{Riwayat Hidup Ibnu Taimiyyah}

Nama lengkapnya adalah Abul Abbas Taqiuddin Ahmad bin Abdul Al Hamim bin Abdus Salam bin Abdullah bin Taimiyah. Beliau lahir pada tanggal 22 Januari 1263 M (10 Rabiul Awwal 661 H). Di Harran, Turki. Beliau berasal dari keluarga religius. Ayahnya Syihabuddin bin Taimiyah adalah seorang Syaikh, hakim, dan khatib. Kakeknya Majduddin Abul Birkan Abdussalam bin Abdullah bin Taimiyah al Harrani adalah seorang ulama yang menguasai fiqih, Hadits, tafsir, ilmu ushul dan penghafal Al Qur'an (hafidz).Ibnu Taimiyyah lahir di zaman ketika Baghdad merupakan pusat kekuasaan dan budaya Islam pada masa Dinasti Abbasiyah.

Ketika berusia tujuh tahun (tahun 1262), Ibnu Taimiyyah dibawa ayahnya ke Damaskus disebabkan serbuan tentara Mongol atas IrakPada usia yang sangat muda Ibnu Taimiyyah telah menyelasaikan pendidikannya dalam berbagai bidang di antaranya bidang yurisprudensi (fiqh), hadist nabi, tafsir Al-Quran, matematika, dan filsafat. Guru Ibnu Taimiyyah berjumlah 200 orang, di antarannya adalah Syamsuddin Al-Maqdisi, Ahmad bin Abu Al-khair, Ibnu Abi Al-Yusr, dan Al- Kamal bin Abdul Maijd bin Asakir, Yahya bin al-Syairafi, dan yang lainyaSejak kecil sudah terlihat tanda-tanda kecerdasannya. Begitu tiba Sejak kecil sudah terlihat tanda-tanda kecerdasannya.

Begitu tiba di Damaskus,ia segera menghafalkan Al-Qur'an dan mencari berbagai cabang ilmu pada para ulama, hafizh dan ahli Hadits negeri itu. Kecerdasan serta kekuatan otaknya membuat para tokoh ulama tersebut tercengang. Ketika umurnya belum mencapai belasan tahun, ia sudah menguasai ilmu ushuluddin dan mendalami bidang-bidang tafsir, Hadits, dan bahasa Arab. Ia telah mengkaji Musnad Imam Ahmad sampai beberapa kali, kemudian Kutubu Sittah dan Mu'jam At-Thabarani AlKabir.Kehidupan Ibnu Taimiyyah tidak hanya terbatas pada dunia buku dan kata-kata. Ketika kondisi menginginkannya, tanpa ragu-ragu ia turut serta dalam dunia politik dan 


\section{Amir Salim, Muharir, Alda Hermalia, Pemikiran Ibnu Taimiyah dalam Harga}

urusan publik. Dengan kata lain, keistimewaan dari Ibnu Taimiyyah tidak hanya terbatas pada kepiawaiannya dalam menulis dan berpidato, tetapi juga mencakup keberaniannya dalam berlaga dimedan perang Penghormatan yang begitu besar yang diberikan masyarakat dan pemerintah kepada Ibnu Taimiyyah membuat sebagian orang merasa iri dan berusaha untuk menjatuhkan dirinya.

Sejarah mencatat bahwa sepanjang hidupnya, Ibnu Taimiyyah telah menjalani masa tahanan sebanyak empat kali akibat fitnah yang dilontarkan para penentangnya Beliau wafat di dalam penjara Qal'ah Dimasyq yang disaksikan oleh salah seorang muridnya bernama Ibnul Qayyim. Ia bada di penjara ini selama dua tahun tiga bulan dan beberapa hari, mengalami sakit dua puluh hari lebih. Jenazahnya dishlmatkan di masjid Jami Bani Umayah sesudah shlmat Zhuhur yang dihadiri para pejabat pemerintah, ulama, tentara dan para penduduk. Ia wafat pada tanggal 20 DzulHijjah $728 \mathrm{H}$ dan dikuburkan pada waktu Ashar di samping kuburan saudaranya yang bernama Syaikh Jamal AlIslamSyarafuddin (Islahi 1997).

\section{Karya karya Ibnu Taimiyah}

Ibnu Taimiyyah memiliki banyak karya ilmiah yang sangat fantastis. Ia memiliki banyak karya buku yang menguraikan tentang hukum, ekonomi, filsafat dan masih banyak lagi yang lainnya. Para peneliti tidak bisa menentukan berapa banyak jumlah buku yang dikarang oleh Ibnu Taimyah. Namun mereka dapat memperkirakan sekitar 300-500 buah buku karya ilmiah yang dibuat oleh Ibnu Taimiyah baik dalam jumlah besar maupun dalam jumlah kecil.Penulis kitab Fatawat al-Wafayat menyebutkan karangan-karangan Ibnu Taimiyah mencapai 300 buah buku di antaranya; Majmu'Fatawa Syaikh al-Islam, Iqtitip al-Siratal Mustaqim wa Mukhlmafah Ashab al Jahir, al Sarim al Maslul 'Ula Syatim al Rasul, al Jawab al Salih Liman Baddala Din al Masih, al Jawami fi al Siyasah al Ilahiyah wa al Ayat al Nabawiyah, al-Rass 'ala al Mantiqin, al Siyasah al Syar'iyyah fi Ishlah al Ra'I wa al Ra'Iyah, Fatawa Ibnu Taimiyah, al Hisbah fi al Islam dan sebagainya.

Beliau memahami semua Hadits yang termuat dalam Kutubus Sittah dan AlMusnad. Dalam mengemukakan ayat-ayat sebagai hujjah atau dalil, beliau juga 
memiliki kehebatan yang luar biasa, sehingga mampu mengemukakan kesalahan dan kelemahan para mufassir atau ahli tafsir. Tiap malam beliau menulis tafsir, fiqh, ilmu 'ushul sambil mengomentari para filusuf. Sehari semalam ia mampu menulis empat buah kurrosah (buku kecil) yang memuat berbagai pendapatnya dalam bidang syari'ah. Karyanya yang terkenal adalah Majmu' Fatawa yang berisi Dalam bidang ekonomi beliau membahas tentang prinsip-prinsip ekonomi yang dituliskan dalam dua buku yaitu: al Hisbah fi al Islam ( Lembaga Hisbah dalam Islam) dan al Siyasah al Syari'iyyah fi Ishlah al Ra'I wa al Ra'iyyah (Hukum publik dan privat dalam Islam) yang akan di jelaskan di bab berikutnya.Begitu banyak karya-karya yang dibuat oleh Ibnu Taimiyyah yang memberikan perubahan terhadap perkembangan dunia Islam, berkat gagasan dan wawasan keilmuannya beliau dikenal sebagai pembaharu dengan pengertian memurnikan ajaran agama Islam agar tidak tercampur dengan hal-hal yang berbau bid'ah.

\section{PEMBAHASAN}

\section{A. Pandangan Ekonomi menurut Ibnu Taimiyyah}

Ekonomi Islam ialah suatu ilmu pengetahuan yang berupaya memandang, meninjau, meneliti yang pada akhirnya menyimpulkan dan menyelesaikan permasalahan-permasalahan ekonomi dengan cara-cara Islami yakni yg dilandasi oleh Al-Quran dan Hadits . Titik tekan ilmu ekonomi Islam adalah bagaimana Islam memberikan pandangan dan solusi atas berbagai persoalan ekonomi yang dihadapi umat secara umum. Tidak dapat dipungkiri dan digambarkan bilamana masalah perekonomian Islam ini akan diabaikan oleh seorang filosof yang sangat jenius dan bahkan sangat di akui pada masanya, yakni Ibnu Taimiyyah. Ia menyaksikan dengan mata kepalanya sendiri ketika sejumlah keluarganya bangkrut dan tentunya kehidupan ekonomi mereka berada karena berada di ombang ambing kebangkrutan tersebut, kehidupan perekonomian mereka sangat miris bahkan bisa dikatakana berantakan, yakni dari semenjak awal kehidupannya.

Ibnu Taimiyyah juga membahas prinsip prinsip akan permasalahan ekonomi dalam dua buku, di antaranya Al-Hisbah fi'l-Islam yakniLembaga Hisbah dalam Islam dan alSyiasah al-Syariah fi Islah al-Rai wa'l-Ra'iyah yakni Hukum public dan privat dalam 
$160 \mid$ Amir Salim, Muharir, Alda Hermalia, Pemikiran Ibnu Taimiyah dalam Harga

Islam. Dalam buku pertama, ia banyak membahas tentang pasar dan intervensi pemerintah dalam kehidupan ekonomi. Dan dalam buku kedua, ia membahas akan masalah pendapatan dan pembiayaan publik.Terpisah dengan dua buku tersebut, sejumlah karya tulis juga menggali berbagai masalah yang berkaitan dengan masalah ekonomi. Meskipun terkadang, kajiannya terlalu meluas, sehingga pandangannya mengenai ekonomi hamper bisa ditemukan dalam seluruh bukunya (Azhim 2005).

\section{B. Pokok Pemikiran Ibnu Taimiyyah Dalam Harga, Pasar dan Hak Milik}

Di dalam penelitian ini, penulis hanya menjelaskan 3 pokok pemikiran Ibnu Taimiyyah, yang mana pemikiran ekonomi ini menjadi pokok atau menjadi suatu kajian yang menarik untuk di aplikasikan kedalam tulisan ini, pertama Harga Yang Adil, kedua Pasar Yang Sehat dan ketiga Hak Milik. Berikut ini adalah penjelasan dalam hal tersebut.

\section{a. Harga Yang Adil}

Ketika membahas harga yang adil maka terdapat pula sebuah mekanisme di dalam harga, mekanisme harga yakni suatu proses yang berjalan atas dasar gaya tarik menarik antara konsumen dan produsen, baik dari pasar Output (barang) ataupun input (faktorfaktor produksi). Adapun harga dapat diartikan sebagai sejumlah uang yang menyatakan nilai tukar suatu unit benda tertentu.Harga yang adil menurut Ibnu Taimiyyah adalah "Nilai harga di manaorang-orang menjual barangnya dan diterima secara umum sebagai hlm yang sepadan dengan barang yang dijual ataupun barang-barang yang sejenis lainnya di tempat dan waktu berbeda".

Konsep Ibnu Taimiyyah yang seringkali ditemukan dalam pembahasan tentang permasalahan harga, yakni kompensasi yang setara/adil ('Iwad al-Mitsl) dan harga yang setara/adil (Tsaman al-Mitsl). Dia berkata :" Kompensasi yang setara akan diukur dan ditaksir oleh hlm-hlm yang setara, dan itulah esensi dari keadilan (Nafs al- 'Adl)".Iwadh al-Mitsl adalah penggantian yang sama yang merupakan nilai harga sepadan dari sebuah benda menurut adat kebiasaan. Adapun Tsaman al-Mitsl adalah nilai harga di mana orang-orang menjual barangnya dapat diterima secara umum sebagai hal yang sepadan dengan barang yang dijual itu. Keadilan yang dikehendaki oleh Ibnu Taimiyyah berhubungan dengan prinsip La Dharar yakni tidak melukai dan tidak merugikan orang 
Ekonomica Sharia: Jurnal Pemikiran dan Pengembangan Ekonomi Syariah Volume 6 Nomor 2 Edisi Februari 2021 | 161

lain, dengan berbuat adil maka tidak akan terjadi kezaliman. Permasalahan tentang kompensasi yang adil muncul ketika membongkar masalah moral atau kewajiban hukum (berkaitan dengan kepemilikan) (Islahi 1997).

Adapun prinsip-prinsip itu berkaitan dengan kasus-kasus berikut :

1. Ketika seseorang bertanggung jawab menyebabkan terluka atau rusaknya orang lain (nufus), hak milik (amwal), keperawanan dan keuntungan ( manafi).

2. Ketika seseorang mempunyai kewajiban membayar kembali barang atau profit yang setara atau membayar ganti rugi atas terluka nya salah satu bagian dari anggota tubuhnya.

3. Ketika seseorang dipertanyakan telah membuat kontrak tidak sah (al-Uqud alFasidah) ataupun kontrak yang sah (al-Uqud al-Shlmihah) pada peristiwa yang menyimpang (Arsh) dalam kehidupan maupun hak milik.Adapun prinsip umum yang sama berlaku bagi pembayaran iuran, kompensasi dan kewajiban finansial lain misalnya :

1. Suatu hadiah yang diberikan oleh gubernur (wali) kepada anak yatim piatu atau hadiah wakaf

2. Kompensasi oleh agen bisnis yang menjadi wakil untuk melakukan pembayaran kompensasi.

3. Adanya pengupahan oleh atau kepada rekan bisnis (al-musharik wa'l-mudarib), dan sebagainya. Tentunya di dalam kasus-kasus ini tidak merupakan kasus nilai tukar, tetapi sebagai kompensasi atas pelaksaan sebuah kewajiban. Tentang kompensasi yang setara dan harga yang setara, ia menguraikan ada 2 macam jumlah kuantitas yang tercatat dalam kontrak. Pertama, jumlah kuantitas yang sangat akrab di masyarakat, yang biasa mereka gunakan.Kedua, jenis yang tak lazim (nadir),sebagai akibat dari menigkat atau menurunnya kemauan (raghabah) atau factor lainnya.Dalam analisa ekonomi dianggap bahwa permintaan suatu barang terutama dipengaruhi oleh tingkat harganya.Dalam hukum permintaan diuraikan sifat hubungan antara permintaan barang dengan tingkat harganya. Hukum permintaan menyatakan : "Makin rendah harga suatu barang maka makin banyak permintaan terhadap barang tersebut. Sebaliknya, makin tinggi harga suatu barang maka makin sedikit permintaan terhadap barang tersebut”. Begitu juga 


\section{2}

Amir Salim, Muharir, Alda Hermalia

sebaliknya, hukum penawaran yang menjelaskan tentang hubungan antara harga suatu barang dengan jumlah barang yang ditawarkan oleh penjual.Ibnu Taimiyyah menyebutkan dua sumber penyediaan barang (supply) yaitu produksi lokal dan impor yang diminta.

Konsep harga adil Ibnu Taimiyyah hanya terjadi pada pasar kompetitif, tidak ada pengaturan yang menggangu keseimbangan harga kecuali jika terjadi suatu usaha-usaha yang menggangu terjadinya keseimbangan, yaitu kondisi di mana semua faktor produksi digunakan secara optimal dan tidak ada ide, sebab harga pasar kompetitif merupakan kecenderungan yang wajar. Untuk menerapkan harga yang adil Ibnu Taimiyyah menentang adanya praktek monopoli terhadap kebutuhan-kebutuhan manusia. Jika ada sekelompok manusia yang melakukan monopoli maka wajib bagi pemerintah untuk melakukan regulasi atau pengaturan terhadap harga. Tujuan utama dari harga yang adil adalah memelihara keadilan dalam mengadakan transaksi timbal balik diantara masyarakat.

\section{b. Mekanisme Pasar}

Ibnu Taimiyyah juga memiliki pandangan yang jernih dalam sebuah pasar bebas, Harga sangat dipertimbangkan oleh kekuatan penawaran dan permintaan. Menurutnya, naik dan turunnya angka dari sebuah harga itu tidak selalu berkaitan dengan Kezaliman (zulm) yang dilakukan oleh seseorang. Meskipum alasannya adalah adanya kekurangan dalam produksi atau penurunan impor dari barang-barang yang diminta. Oleh karna itu, jika membutuhkan peningkatan jumlah barang, sementara produksinya menurun maka dalam kasus-kasus seperti ini bisa dipastikan adanya kenaikan harga. Dalam kasus lain, jika kemampuan dalam produksi barang meningkat, namun dalam permintaan konsumen menurun maka dapat di pastikan harga juga akan turun. Karna kelangkaan dan kelimpahan suatu barang itu tidak mesti diakibatkan oleh perbuatan satu pihak. Namun hal ini dapat terjadi apabila terdapat suatu ketidakadilan. Dari pernyataan di atas dapat di analisis bahwasannya ada kebiasaan yang tidak baik tepatnya pada zaman Ibnu Taimiyyah, kenaikan harga itu terjadi akibat adanya ketidakadilan atau malpraktik dari para produsen. 
Kata yang paling actual yang sering digunakan oleh Ibnu Taimiyyah adalah zulm, yang berarti sebuah pelanggaran hukum atau lebih tepatnya ketidakadilan. Pada kasus seperti ini, digunakan dalam pengertian manipulasi oleh penjual, yang mendorong terjadinya ketidakseimbangan pasar.Ibnu Taimiyyah Mengatakan bahwasannya ada dua sumber di dalam penyediaan barang yakni, Produksi barang dan impor barang yang diminta (ma yukhlak aw-yujlab min dhlmik al-mal al-matlub). Makna dari al-matlub adalah sinonim dari Bahasa inggris"demand". Untuk menyatakan permintaan atas barang tertentu, Ibnu Taimiyyah menggunakan ungkapan raghbat fi al-shai'. Misalnya keinginan atas suatu barang. Keinginan itu terefleksi dalam bentuk keinginan atau selera, merupakan salah satu pertimbangan penting dari permintaan.

Pasal yang di kutip di atas memberi kesan bahwasannya Ibnu Taimiyyah menunjukan pada sesuatu yang kini disebut fungsi penawaran dan permintaan. Ketika terjadi sebuah lonjakan akan permintaan pada harga yang sama dan kekurangan kekurangan penyediaan pada harga yang sama pula. Sebaliknya, kekurangan permintaan dan kelebihan suplai pada harga yang sama, alhasil akan terjadinya dorongan untuk penurunan harga. Tidak dapat dipungkiri lagi, jika penurunan suplai disertai dengan peningkatan permintaan maka akan terjadilah kenaikan dalam harga.Di dalam satu bagian bukunuya Fatawa, Ibnu Taimiyyah mencatat beberapa faktor yang berpengaruh terhadap permintaan dan konsekuensinya terhadap harga yakni:

a. Perubahan juga tergantung pada jumlah para peminta (tullab). Jika jumlah dari orang-orang yang meminta dalam satu jenis barang dagangan banyak, maka harga akan naik dan akan terjadi sebaliknya jikalau jumlah permintaan sedikit.

b. Keinginan penduduk (al-raaghbah) atas jenis yang berbeda-beda dan sesekali berubah-ubah. Perubahan itu sesuai dengan kelimpahan atau kelangkaan barang yang diminta (al-matlub). Sebuah barang sangat di inginkan jika persediaannya sangatlah sedikit.

c. Harga juga berubah-ubah, sesuai dengan siapa saja dalam pertukaran barang tersebut dilakukan (al-mu'awid). Jika ia kaya dan dijamin membayar hutang maka harga bisa turun untuknya. Daripada yang di terima dari orang lain yang diketahui sedang dalam kebangkrutan, suka menunda pembayaran, atau diragukan dalam melakukan pembayaran. 


\section{$164 \mid$}

Amir Salim, Muharir, Alda Hermalia,

d. Jikalau tingkat kebutuhan atas suatu barang ini menguat ataupun melemah ini bisa berpengaruh dalam kenaikan harga karna meluasnya jumlah dan ukuran dari kebutuhan baik besar maupun kecil.

Harga juga dapat dipengaruhi oleh bentuk alat pembayaran yang digunakan dalam jual beli. Jika yang digunakan umum dipakai (naqd ra'ji), harga akan lebih rendah daripada membayar dengan uang yang jarang ada di peredaran.

\section{c. Hak Milik}

Dalam Islam Allah lah pemilik yang sesungguhnya dan mutlak. Menurut Ibnu Taimiyah, penggunaan hak milik dimungkinkan sejauh tidak bertentangan dengan prinsip-prinsip syariat. Hak milik bagi Ibnu Taimiyyah yakni sebuah kekuatan yang didasari atas suariat untuk menggunakan sebuah objek, Namun kekuatan itu sangatlah bervariasi dalam bentuk dan tingkatannya. Misalkan, kekuatan itu sesekali sangat lengkap, sehingga pemilk benda tersebut berhak menjual, meminjamkan ataupun menghadiahkan bahkan menggunakannya untuk tujuan produktif.

Akan tetapi, sekali tempo maka kekuatan tersebut tidak akan lengkap lagi, karna hak dari pemilik itu terbatas. Pembahasan Ibnu Taimiyyah tidak dibatasi oleh hak milik pribadi, namun juga mencangkup kepemilikan oleh masyarakat maupun negara. Dalam masalah seperti ini, pandangan akan masalah karakteristik ekonominya.

1. Hak Milik Individu.

Setiap individu tentunya memiliki hak untuk menikmati hak miliknya karna kerja keras yang telah dilakukannya tersebut, yakni dengan menggunakannya secara produktif, memindahkannya dan melindunginya dari pemubaziran yang terbuang siasia. Oleh karna itu Ia tidak boleh menggunakannya secara berlebihan untuk tujuan bermewah-mewahan. Oleh karna itu hak milik individu ini dibatasi oleh sebuah kesederhanaan.

2. Hak Milik Sosial atau Kolektif.

Hak milik sosial memiliki bentuk yang bermacam-macam. Misalnya, sebuah objek bisa saja dimiliki oleh dua orang atau lebih, organisasi atau asosiasi. Contoh penting dari kepemilikan bersama adalah anugerah alam, seperti air, rumput dan api yang juga disebutkan dalam hadis Rasulullah Saw. "manusia itu berserikat (dalam pemanfaatan) 
tiga alam, yaitu air, rumput dan api”. (HR Ahmad bin Hambal). Salah satu alas an dari keharusan pemilikan kolektif terhadap obyek-obyek alam adalah semua itu diberikan oleh Allah seacara gratis dan semua itu demi kepentingan umum.

3. Hak Milik Negara.

Di dalam suatu negara tentunya membutuhkan hak milik untuk memperoleh pendapatan, sumber-sumber penghasilan dan kekuasaan untuk melaksanakan kewajibannya, seperti untuk menyelenggarakan pendidikan, regenerasi moral, memelihara keadilan, memelihara hukum dan secara umum melindungi seluruh kepentingan material dan spiritual penduduk. Menurut Ibnu Taimiyah, sumber utama dari pendapatan negara itu adalah zakat dan harta rampasan perang (ghanimah).

\section{SIMPULAN}

Asas Pemikiran Ibnu Taimiyyah merupakan hasil dialog kritis dengan fenomena sosial, ekonomi dan politik pada zamannya. Ia telah memberikan inspirasi tentang bagaimana sebuah Negara berperan dalam pembangunan, khususnya pembangunan ekonomi. Solusi yang ditawarkan Ibnu Taimiyah adalah negara hendaknya menjadi supervisor moralitas pembangunan untuk menyadarkan rakyatnya bahwa betapa pentingnya norma moral dan nilai etika sebagai asas pembangunan dan dapat mewujudkannya dalam kehidupan perekonomian.Sikap Ibnu Taimiyyah berada antara dua larangan yang sama-sama ekstrem, yakni secara absolut melarang dan hak pemerintah mengatur harga tanpa syarat. Dalam menetapkan harga, tingkat tertinggi dan terendah bisa ditetapkan, sehingga kepentingan dua pihak, yakni penjual dan pembeli terlindungi. Ahli fiqih juga sepakat bahwa seorang bisa dipaksa untuk menjual barang dagangan pada tingkat harga yang setara, jika ia secara hukum terikat untuk menjualnya. 
166 | Amir Salim, Muharir, Alda Hermalia, Pemikiran Ibnu Taimiyah dalam Harga..................

\section{DAFTAR PUSTAKA}

Al-Amwal. (2017). Pemikiran Ekonomi Ibnu Taimiyah. Journal of Islamic Economic Law, No. 2.

Arifin, Z. (2009). Dasar-Dasar Manajemen Bank Syariah. Tanggerang: Azkia Publisher.

Azhim, S. S. (2005). Taimiyah Pembaharuan Salafi dan Dakwah. Jakarta: Pusstaka ALKautsar.

Islahi., A. (1997). Konsepsi Ekonomi Ibnu Taimiyah. Jakarta: Pustaka Asatruss.

Meriyati. (2016). Pemikiran Tokoh Ekonomi Islam: Ibnu Taimiyah. Islamic Banking, Nomor 1.

Moleong, Lexy. J. (2000). Metodologi Penelitian Kualitatif, (Bandung: PT Remaja Rosdakarya

Sulistyo, Basuki. (20060. Metode Penelitian. Jakarta: Wedatama Widya Sastra

Silalahi, Ulber. (2009). Metode Penelitian Sosial.Bandung : PT. Refika Aditama 